\title{
Sodium content of bread from bakeries and traditional markets in Maputo, Mozambique
}

\author{
Vânia Silva ${ }^{1,2}$, Patrícia Padrão ${ }^{1,3, *}$, Célia Novela ${ }^{4}$, Albertino Damasceno ${ }^{4,5}$, \\ Olívia Pinho', Pedro Moreira ${ }^{1,3,6}$ and Nuno Lunet ${ }^{3,5}$ \\ ${ }^{1}$ Faculty of Nutrition and Food Sciences, University of Porto (FCNAUP), Rua Dr. Roberto Frias, 4200-465 Porto, \\ Portugal: ${ }^{2}$ Faculty of Sciences, University of Porto (FCUP), Porto, Portugal: ${ }^{3}$ Institute of Public Health, University of \\ Porto (ISPUP), Porto, Portugal: ${ }^{4}$ Faculty of Medicine, Eduardo Mondlane University, Maputo, Mozambique: \\ ${ }^{5}$ Department of Clinical Epidemiology, Predictive Medicine and Public Health, Faculty of Medicine, University of Porto \\ (FMUP), Porto, Portugal: ${ }^{\circ}$ Research Centre in Physical Activity, Health and Leisure, University of Porto, Porto, Portugal
}

Submitted 30 May 2013: Final revision received 20 January 2014: Accepted 14 March 2014: First published online 30 April 2014

\begin{abstract}
Objective: The Na content of bread is one of the most common targets of initiatives to reduce $\mathrm{Na}$ intake worldwide. Assessing the $\mathrm{Na}$ content of staple foods is of major relevance in Mozambique, given the high burden of hypertension in this setting. We aimed to estimate the Na content of white bread available in different bakeries and markets in Maputo.

Design: A cross-sectional study of the Na content of white bread available for sale at twenty-five bakeries and markets in Mozambique. Flame photometry was used to quantify the $\mathrm{Na}$ content of the bread. The percentage of samples meeting manufacturer $\mathrm{Na}$ targets from South Africa and six countries from other regions, selected as benchmarks, was computed.

Setting: Maputo, Mozambique.

Subjects: Three loaves of white bread from each selected bakery/market.

Results: The mean $\mathrm{Na}$ content of bread was $450.3 \mathrm{mg} / 100 \mathrm{~g}$ (range: 254.9-638.3 mg/100 g), with no significant differences between bakeries and traditional markets. Most samples ( $88 \%$ ) did not meet the regulation in South Africa $(\leq 380 \mathrm{mg} / 100 \mathrm{~g})$. When considering the targets from other countries (range: $\leq 360-550 \mathrm{mg} / 100 \mathrm{~g}$ ), the prevalence of non-compliance varied between $8 \%$ and $92 \%$. There were no significant differences in the price of bread with $\mathrm{Na}$ content below and above the targets.

Conclusions: The content of $\mathrm{Na}$ in bread varies widely in Mozambique, reaching high values in a high proportion of the bakeries and markets in Maputo. Measures to regulate the $\mathrm{Na}$ content in bread may contribute to a reduction in $\mathrm{Na}$ intake and improved health at the population level.
\end{abstract}

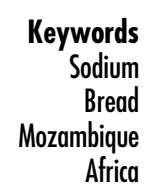

High $\mathrm{Na}$ intake is strongly associated with high blood pressure $^{(1)}$ and stroke, being responsible for an estimated 4.0 million deaths worldwide in $2010^{(2)}$. The WHO recommends no more than $2 \mathrm{~g} \mathrm{Na} / \mathrm{d}$ (equivalent to $5 \mathrm{~g}$ salt $(\mathrm{NaCl}) / \mathrm{d})$ in adults, in order to reduce the burden of noncommunicable diseases ${ }^{(3)}$. However, in all countries with recent data available the dietary $\mathrm{Na}$ intake is much higher than recommended ${ }^{(4)}$. To our knowledge, no such data from Mozambique have been published, despite Na intake being of major relevance in this setting given the high prevalence of hypertension (25-64 years: $33 \cdot 1 \%$ in 2005), the low proportion of hypertensive individuals under pharmacological treatment $(39.9 \%$ from the $14.8 \%$ who were aware of their condition) ${ }^{(5,6)}$ and the increasing public health impact of CVD. It is estimated that the number of deaths due to CVD almost doubled in Mozambique in the last two decades (from nearly 9000 in 1990 to almost 17000 in 2010) ${ }^{(7)}$. In 2005-2006, the incidence of stroke hospitalization in Maputo among those aged $\geq 25$ years was estimated to be one of the highest in developing settings (adjusted incidence rate, world standard population: $260 \cdot 1$ per 100000$)^{(8)}$ and the early case-fatality rate was also high ${ }^{(9)}$.

Although the sources of Na differ across high- and lowincome countries, bread appears to be one of the most important contributors to overall $\mathrm{Na}$ intake worldwide ${ }^{(10)}$. In Mozambique, starchy foods are the major staple foods; the consumption of cassava and maize prevails in the 
north of the country and bread intake is higher in the south $^{(11,12)}$, being sold in bakeries and traditional markets (both formal and informal street markets). Data from the last Household Budget Survey showed that, in Maputo city, the daily per capita availability of bread was $106 \mathrm{~g}^{(13)}$.

There are no manufacturer $\mathrm{Na}$ targets for bread in Mozambique but in neighbouring South Africa, the Government has regulated the $\mathrm{Na}$ content of processed foods, including bread, by stipulating a target of $380 \mathrm{mg} / 100 \mathrm{~g}$ for the maximum $\mathrm{Na}$ content of bread, which will became mandatory after June 2019 ${ }^{(14)}$. For other countries worldwide, the targets range from $360 \mathrm{mg} /$ $100 \mathrm{~g}$ to $550 \mathrm{mg} / 100 \mathrm{~g}^{(15-19)}$.

The present study aimed to estimate the Na content of white bread available in different bakeries and markets in Maputo, Mozambique.

\section{Experimental methods}

\section{Selection of the bakeries and markets and collection of samples}

All bakeries ( $n$ 16) situated in Maputo city that were listed in the Mozambican Yellow Pages ${ }^{(20)}$ were identified, as well as the major traditional markets in the same urban area, including officially organized retail outlets confined to an area fitted for the purpose (formal traditional markets, $n 3$ ) and non-organized street markets (informal traditional markets, $n 5$ ). Additionally, a well-known bakery chain with four retail stores was identified and their largest bakery was included in the sample of bakeries and markets, increasing the number of bakeries visited to seventeen.

Three loaves of white bread (bread made from wheat flour from which the darker, coarser bran has been removed, retaining the starchy endosperm ${ }^{(21)}$ ) were bought in June 2012, in each of the twenty-five bakeries/ markets, and their prices were noted. Only one type of bread (white bread) was available in the selected bakeries and markets.

Each group of three loaves was then weighed, packed in proper cooler bags (one bag for each bakery/market) and frozen at $-18^{\circ} \mathrm{C}$ until $\mathrm{Na}$ content analysis.

\section{Na determination}

After defrosting to room temperature, the groups of bread from each bakery/market were weighed and ground mechanically for homogenization of each sample. After homogenization, three aliquots, with approximately $2 \mathrm{~g}$ bread each, were collected and prepared for Na determination according to a previously validated method, described in detail elsewhere ${ }^{(22)}$. Briefly, the Na existing in the bread was dissolved in doubly deionized water and quantified by flame photometry (flame photometer model PFP7; JenWay ${ }^{\circledR}$, Dunmow, UK).

Two readings of each of the three aliquots from the same homogenized bread sample were taken. The variation between each group of six results was lower than $5 \%$, and therefore the mean of the six results obtained was considered for data analysis. The final $\mathrm{Na}$ content per $100 \mathrm{~g}$ of bread was adjusted for the difference between the weight of the bread on the day of purchase and on the date of analysis, as follows: final $\mathrm{Na}$ content $=$ (weight of bread at purchase $\times \mathrm{Na}$ content)/weight of bread at analysis.

\section{Non-compliance with recommendations for the level of Na in bread}

In Mozambique there are no specific guidelines for the maximum $\mathrm{Na}$ content of bread, and therefore our results were interpreted according to the maximum levels allowed or recommended in countries where those guidelines exist, including neighbouring South Africa and countries from other regions across the globe, namely Australia, Finland, New Zealand, Portugal, the UK and the USA (see Table 1 footnotes for a more detailed description).

\section{Statistical analysis}

For the samples collected in bakeries and traditional markets, comparisons were made with respect to the distribution of price (Mann-Whitney $U$ test) and $\mathrm{Na}$ content ( $t$ test for independent samples) of bread and the prevalence of non-compliance with the manufacturer $\mathrm{Na}$ targets established by different countries (using the $\chi^{2}$ test). A significance value of 0.05 was used.

\section{Results}

Overall, the price per $100 \mathrm{~g}$ of bread varied between $2 \cdot 2$ and 6.2 meticais (between \$US 0.08 and \$US 0.22), the median price being 3.5 meticais, with no significant differences between the bread available in bakeries and traditional markets (3.2 v. 3.6 meticais, $P=0.288$ ). The mean $\mathrm{Na}$ content of bread was $450.3 \mathrm{mg} / 100 \mathrm{~g}$, ranging between $254.9 \mathrm{mg} / 100 \mathrm{~g}$ and $638.3 \mathrm{mg} / 100 \mathrm{~g}$, with no significant differences between bakeries and traditional markets (Table 1).

A total of $88 \%$ of the samples did not comply with the target defined in South Africa $(\leq 380 \mathrm{mg} / 100 \mathrm{~g})$ and $84 \%$ were above the maximum level of $\mathrm{Na}$ in bread recommended in Australia ( $400 \mathrm{mg} / 100 \mathrm{~g}$ ) and the UK ( $400 \mathrm{mg} / 100 \mathrm{~g}$ ). In just over half (56\%) the Na levels were higher than the threshold recommended in New Zealand ( $450 \mathrm{mg} / 100 \mathrm{~g})$, whereas only $8 \%$ exceeded the less restrictive limit imposed by the Portuguese Government $(550 \mathrm{mg} / 100 \mathrm{~g})$. The $\mathrm{Na}$ content of nearly all samples $(23 / 25)$ did not comply with the target recommended in the USA $(360 \mathrm{mg} / 100 \mathrm{~g})$ and did not meet the requirement for a 'reduced salt' label $(360 \mathrm{mg} / 100 \mathrm{~g})$ in Finland. Seven (out of twenty-five) bakeries/markets had bread with an $\mathrm{Na}$ content that exceeded the threshold at which a 'highly salty' label is required, according to the Finish guidelines (480 mg/100 g; Table 1). 
Table 1 Sodium content of white bread samples from Maputo city, Mozambique

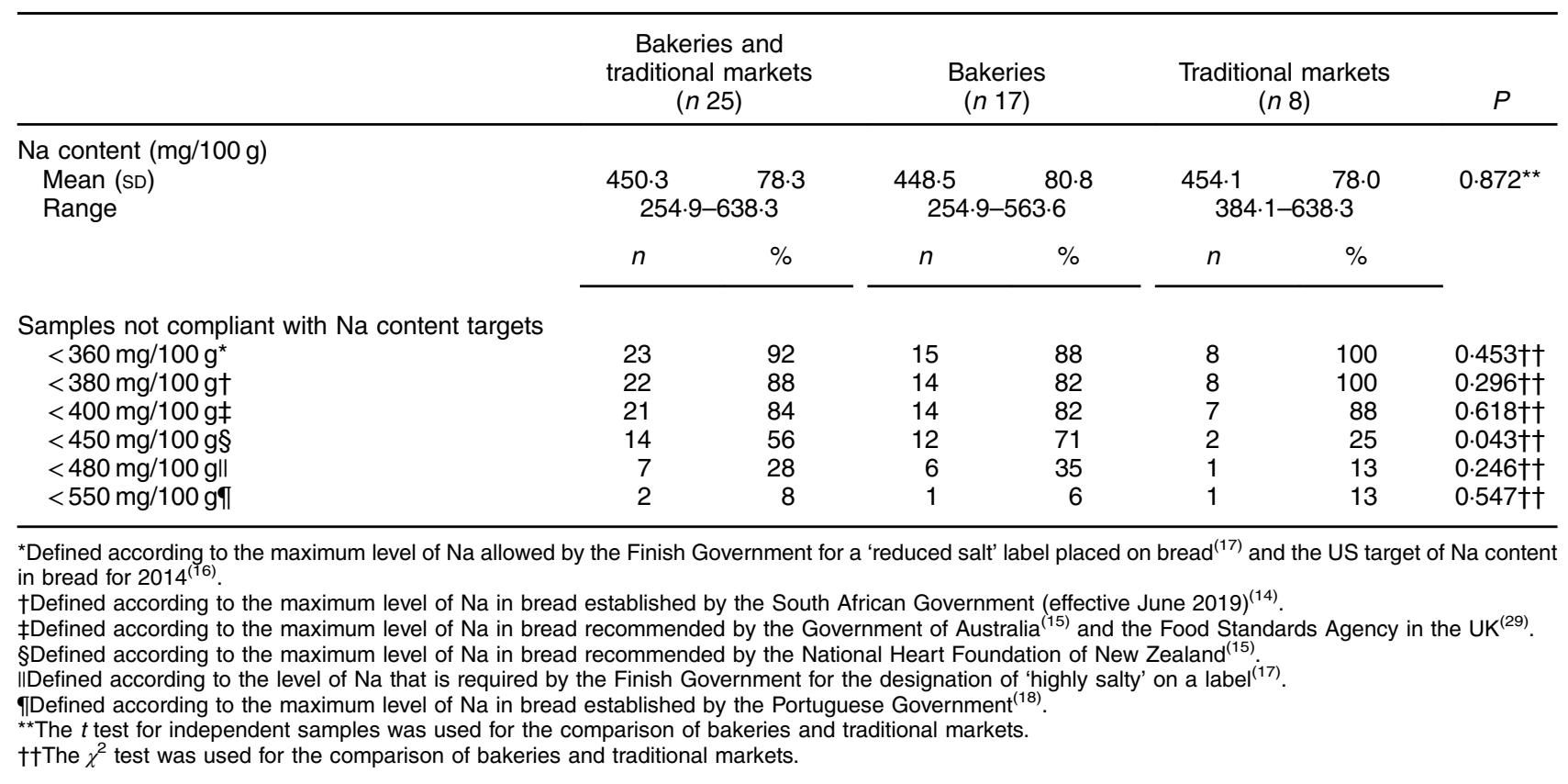

There were no statistically significant differences in the price of bread with $\mathrm{Na}$ content below and above the targets defined internationally (e.g. South African target, median price/100 g: $3 \cdot 1$ meticais (low Na) $v .3 .5$ meticais (high Na), $P=0.742$; Portuguese target, median price/ 100 g: 3.4 meticais (low Na) v. 4.2 meticais (high Na), $P=0 \cdot 355)$.

\section{Discussion}

The mean Na content of bread available for purchase in the most commonly frequented bakeries and markets in Maputo was $450 \mathrm{mg} / 100 \mathrm{~g}$. Despite the wide range of values observed (254.9-638.3 mg/100 g), most samples ( $88 \%$ ) were above the maximum levels recommended in neighbouring South Africa.

Taking into account recent reports on this topic, the mean $\mathrm{Na}$ content of bread was $544 \mathrm{mg} / 100 \mathrm{~g}$ (range: $204-720 \mathrm{mg} / 100 \mathrm{~g}$ ) in a study from Nigeria ${ }^{(23)}$ published in 2013, which is approximately $20 \%$ higher than observed in our survey. On the other hand, the mean $\mathrm{Na}$ level in bread samples collected in Maputo was similar to that reported in 2010 in Australia ( $427 \mathrm{mg} / 100 \mathrm{~g}$ ) and New Zealand $(463 \mathrm{mg} / 100 \mathrm{~g})^{(15)}$, and $12 \%$ higher than that described in 2009 in the UK $(397 \mathrm{mg} / 100 \mathrm{~g})^{(24)}$. These countries have achieved significant reductions in the $\mathrm{Na}$ content of bread as a result of important local efforts. In addition to national actions, broader initiatives such as those developed under the European Union Framework for National Salt Initiatives ${ }^{(25)}$ and the World Action on Salt and Health ${ }^{(26)}$ may be contributing to reductions in the $\mathrm{Na}$ content of bread. The National Salt Reduction Initiative in the USA is also committed to achieving a progressive reduction in $\mathrm{Na}$ intake at a population level; the ambitious target of $360 \mathrm{mg} \mathrm{Na} / 100 \mathrm{~g}$ bread was set to be achieved by $2014^{(16)}$

Bread sold in bakeries was produced on site while that sold in the markets was probably purchased in bakeries, which may help to explain the absence of significant differences in the Na content of bread from bakeries and traditional markets. Nevertheless, we considered that it was important to include traditional markets in our sample of bakeries and markets because they may have a relevant contribution to the sale of bread in Maputo.

The high prevalence of iodine deficiency in Mozambique, which is preventable by the use of iodized salt, could be an argument against the reduction of salt intake. However, salt reduction and salt iodization are compatible ${ }^{(3,27)}$, as long as appropriate monitoring of salt intake at country level is carried out in order to adjust salt iodization over time.

It is expected that the selection of all bakeries registered in the Yellow Pages, as well as all well-known formal and informal traditional markets, resulted in the inclusion of most of the more popular bakeries and markets geographically scattered in Maputo, although some of the smaller bakeries and transient informal markets may have been missed. Also, our findings cannot be extrapolated to the entire country. An additional limitation of our study is the fact that the results are not based on sales data, and therefore do not provide direct evidence of the actual $\mathrm{Na}$ ingested from bread in Maputo.

Further research is needed to assess the overall $\mathrm{Na}$ intake and the sources of $\mathrm{Na}$ in the Mozambican population in order to prioritize the interventions needed to 
reduce the impact of the expected shift towards a more 'industrialized' food pattern. Nevertheless, our results show that, in this setting, the efforts to reduce $\mathrm{Na}$ intake may benefit from measures to regulate its content in bread, in addition to consumer education strategies. A partnership between the government, retailers and manufacturers could be a step towards the reformulation of processed foods in order to decrease their Na content. It would be also important to invest in strategies to overcome technical issues that arise when reducing $\mathrm{Na}$ in processed foods and to ensure the acceptability of foods with reduced $\mathrm{Na}$ content by consumers. The stepwise reduction of the $\mathrm{Na}$ content of food is an affordable measure that may attenuate the perception of $\mathrm{Na}$ reduction $^{(28)}$. Public health policies to reduce the intake of $\mathrm{Na}$ include a blend of these measures, together with public campaigns aiming to increase the population's awareness of healthy eating.

\section{Acknowledgements}

Acknowledgements: The authors would like to thank Susana Pasadas for her valuable help during the field work. Financial support: This work was supported by Fundação para a Ciência e Tecnologia (FCT), Projeto Pest OE/SAU/UI0617/2011. FCT had no role in the design, analysis or writing of this article. Conflict of interest: None. Authorship: P.P., A.D., P.M. and N.L. were responsible for the conception and design of the study; C.N., P.P. and A.D. were responsible for the collection of data; V.S. and O.P. were responsible for the laboratory analysis of the samples; V.S., P.P., P.M. and N.L. were responsible for the interpretation of data; V.S. and P.P. drafted the manuscript; and all authors reviewed and approved the final version of the manuscript. Ethics of human subject participation: Ethical approval was not required.

\section{References}

1. He FJ, Li J \& MacGregor GA (2013) Effect of longer term modest salt reduction on blood pressure: Cochrane systematic review and meta-analysis of randomised trials. BMJ 346, f1325.

2. Lim SS, Vos T, Flaxman AD et al. (2012) A comparative risk assessment of burden of disease and injury attributable to 67 risk factors and risk factor clusters in 21 regions, 1990-2010: a systematic analysis for the Global Burden of Disease Study 2010. Lancet 380, 2224-2260.

3. World Health Organization (2012) Guideline: Sodium Intake for Adults and Children. Geneva: WHO.

4. Elliott P \& Brown I (2007) Sodium Intakes Around the World. Background Document Prepared for the Forum and Technical Meeting on Reducing Salt Intake in Populations (Paris 5-7th October 2006). Geneva: WHO.

5. Damasceno A, Azevedo A, Silva-Matos C et al. (2009) Hypertension prevalence, awareness, treatment, and control in Mozambique: urban/rural gap during epidemiological transition. Hypertension 54, 77-83.
6. Gama H, Damasceno A, Silva-Matos C et al. (2013) Low prevalence of hypertension with pharmacological treatments and associated factors. Rev Saude Publica 47, 301-308.

7. Institute for Health Metrics and Evaluation (2013) Global Burden of Disease (GBD) Visualizations. http://www. healthmetricsandevaluation.org/gbd/visualizations/country (accessed March 2013).

8. Damasceno A, Gomes J, Azevedo A et al. (2010) An epidemiological study of stroke hospitalizations in Maputo, Mozambique: a high burden of disease in a resource-poor country. Stroke 41, 2463-2469.

9. Gomes J, Damasceno A, Carrilho C et al. (2013) Determinants of early case-fatality among stroke patients in Maputo, Mozambique and impact of in-hospital complications. Int J Stroke 8, 69-75.

10. Joossens JV, Sasaki S \& Kesteloot H (1994) Bread as a source of salt: an international comparison. J Am Coll Nutr 13, 179-183.

11. Barslund MC (2007) Regional Differences in Food Consumption in Urban Mozambique: A Censored Demand System Approach. Discussion Paper no. 07-15. Copenhagen: University of Copenhagen, Department of Economics.

12. Handa S \& Mlay G (2006) Food consumption patterns, seasonality and market access in Mozambique. Dev $S$ Afr 23, 541-560.

13. Ministry of Planning and Development, National Directorate of Studies and Policy Analysis (2010) Poverty and Wellbeing in Mozambique: Third National Poverty Assessment. Maputo: DNEAP.

14. South African Government, Department of Health (2013) Regulations relating to the reduction of sodium in certain foodstuffs and related matters. Government Gazette No. 36274 of 20 March 2013.

15. Dunford E, Eyles H, Mhurchu C et al. (2011) Changes in the sodium content of bread in Australia and New Zealand between 2007 and 2010: implications for policy. Med J Aust 195, 346-349.

16. Labarthe DR (2011) Sodium Reduction: Facts and Fiction. Atlanta, GA: Division for Heart Disease and Stroke Prevention, National Center for Chronic Disease Prevention and Health Promotion, Centers for Disease Control and Prevention; available at http://www.cdc.gov/about/grandrounds/archives/2011/April2011.htm

17. Pietinen P (2009) Finland's Experiences in Salt Reduction. Helsinki: National Institute for Health and Welfare.

18. Portuguese Government (2009) Lei n. ${ }^{\circ}$ 75/2009 de 12 de agosto. Normas com vista à redução do teor de sal no pão bem como informação na rotulagem de alimentos embalados destinados ao consumo humano [Standards to reduce the salt content in bread as well as information on the labeling of packaged foods intended for human consumption]. Diário da República 1. a série, N. . 155, 5225-5226.

19. Wyness LA, Butriss JL \& Stanner SA (2012) Reducing the population's sodium intake: the UK Food Standards Agency's salt reduction programme. Public Health Nutr 15 , 254-261.

20. Listas Telefónicas de Moçambique Lda (2012) Padarias em Maputo (Bakeries in Maputo). Mozambique: Directory of Yellow Pages in Mozambique.

21. Welch RW (2005) Cereal grains. In Encyclopedia of Human Nutrition, 2nd ed., pp. 346-357 [B Caballero, L Allen and A Prentice, editors]. Oxford: Elsevier.

22. Vieira E, Soares ME, Ferreira IM et al. (2011) Validation of a fast sample preparation procedure for quantification of sodium in bread by flame photometry. Food Anal Meth $\mathbf{5}$, 430-434.

23. Nwanguma BC \& Okorie CH (2013) Salt (sodium chloride) content of retail samples of Nigerian white bread: implications for the daily salt intake of normotensive and hypertensive adults. J Hum Nutr Diet 26, 488-493. 
24. Ni Mhurchu C, Capelin C, Dunford EK et al. (2011) Sodium content of processed foods in the United Kingdom: analysis of 44,000 foods purchased by 21,000 households. Am J Clin Nutr 93, 594-600.

25. World Health Organization (2013) Mapping Salt Reduction Initiatives in the WHO European Region. Copenhagen: WHO Regional Office for Europe.

26. World Action on Salt and Health (2013) Home page. http:// www.worldactiononsalt.com/index.html (accessed April 2013).
27. Vandevijvere S (2012) Sodium reduction and the correction of iodine intake in Belgium: Policy options. Arch Public Health 70, 10

28. Buttriss JL (2013) Food reformulation: the challenges to the food industry. Proc Nutr Soc 72, 61-69.

29. Food Standards Agency (2009) Agency publishes salt commitments. http://www.food.gov.uk/news-updates/news/ 2010/mar/saltcommitments\#.UUTqBTfRmbA (accessed March 2013). 